\title{
The Effect of User Experience on Customer Satisfaction on Netflix Streaming Services in Indonesia
}

\author{
Mario Alberto Jose Martins ${ }^{1}$, \\ Magister Management Universitas Mercubuana Jakarta, \\ Indonesia $^{1}$
}

\begin{abstract}
Technology has become increasingly sophisticated, all forms offered in the development of very cutting-edge technology. Current technology is supported by a strong internet network base that presents various kinds of creativity. One that gets attention is the widespread use of online streaming media as a basis in an online streaming media streaming plan that is Netflix. This research will discuss where the user experience of Netflix Online Streaming Media Customer Satisfaction. The results of this study were drawn from 150 respondents who are always actively using Netflix online streaming media. This research only focused on the Jakarta area, Indonesia, which is the largest city in Indonesia.
\end{abstract}

Keywords:- Streaming Services, Netflix, User Experience, User Satisfaction.

\section{INTRODUCTION}

The development of online streaming media, where customers are facilitated with an all-round service "online" makes everything easy and practical. With the presence of streaming services that use an internet basis and can be accessed on various types of platforms (Smart TV, Computer, Tablets, and smartphones) and anywhere and anytime provides an experience for every loyal customer who enjoys streaming services for activity and entertainment.

One of the online streaming media that has become a trend in the country is Netflix is becoming a hot conversation in Indonesia. Imagine, the streaming media platform from the United States continues to reap the pros and cons with various attitudes shown by the Government ranging from the Minister of Communication and Information Johny $G$ Plate, Minister of Finance Sri Mulyani, to the Minister of Education Nadiem Makarim.

Netflix was a DVD rental company that emerged since 1997 that was founded by Reed Hastings and Marc Randolph in Scotts Valley, California. Along with the development of technology, Netflix has also turned into a streaming movie service. In the third quarter of 2019, the number of Netflix paid subscribers worldwide reached 158 million. At the same time, free trial customers number 5.5 million.

\author{
Setyo Riyanto ${ }^{2}$ \\ Associate Proffesor Magister Management Mercubuana \\ Jakarta, Indonesia ${ }^{2}$
}

In this research, the researcher wants to examine the extent of the audience of online streaming media in this case user experience, are they very satisfied with the quality and service offerings in Netflix Streaming media.

\section{THEORETICAL BASIS}

\section{A. User Experience}

Based on research (Schrepp et al., 2017) studied and grouped that user experience is with six sub-variables namely attractiveness, perspicuity, efficiency, and dependability, stimulation and novelty is the main scale in measuring user experience for interactive products. The user experience can evaluate products that cover the application area to find out how to measure the business in terms of service.

The user experience that needs to be emulated is to meet the needs of the right customers without having to bother or interfere with other activities. Next come simplicity and elegance that produces a product that is pleasant to have, a pleasure to use. True user experience can go beyond giving customers what they want what they have said or providing a checklist feature. To achieve a high-quality user experience in a company offers, it must be a merging of services between various disciplines, including engineering, marketing, graphic and industrial design, and interface design (Rezaldy \& Telkom, 2019).

According to (Raharjo \& Japarianto, 2017) User Experience is learning that comes from a person's experience of an object which then becomes one's selfreflection on that object. In the Journal (Kharis et al., 2019) User Experience covers aspects of user perception, behavior, even things that involve user emotions. Understanding of user experience or user experience is often interpreted as the achievement of a product or service that is considered successful or failed by its users (Mardalena Hutabarat, 2014).

Users not only choice because they feel comfortable to use but according to their needs (Muhammad et al., 2016). User Experience can show the perceived ease of use and efficiency through user experience in using the system (Kusuma et al., 2016). User Experience will have an impact on user behavior if it is in line with what is expected by the customer in enjoying online streaming shows, in this case, Netflix User Experience. The better the quality of Netflix's 
streaming media services will improve the memorable User Experience for the users of the service.

\section{B. Customer Satisfaction}

Companies that use customer experience realize that the customer buys more than not just a product and service, but the customer buys what the customer will do for feelings that are important to himself (Rezaldy \& Telkom, 2019). Customer satisfaction provides value for customers (customer value). Low quality will cause dissatisfaction with customers, not only customers who feel the service but also have an impact on others (Aryani \& Rosinta, 2010). Consumer satisfaction with service companies is defined as a condition where consumer expectations of service are by the reality received about services provided to consumers (Panjaitan \& Yuliati, 2016). According to (Setyo Riyanto, 2018) Implementation is a process in which strategies and policies are put into action through the development of programs, budgets, and procedures. And Netflix has made that change and is one of the biggest online streaming media today.

\section{Framework}

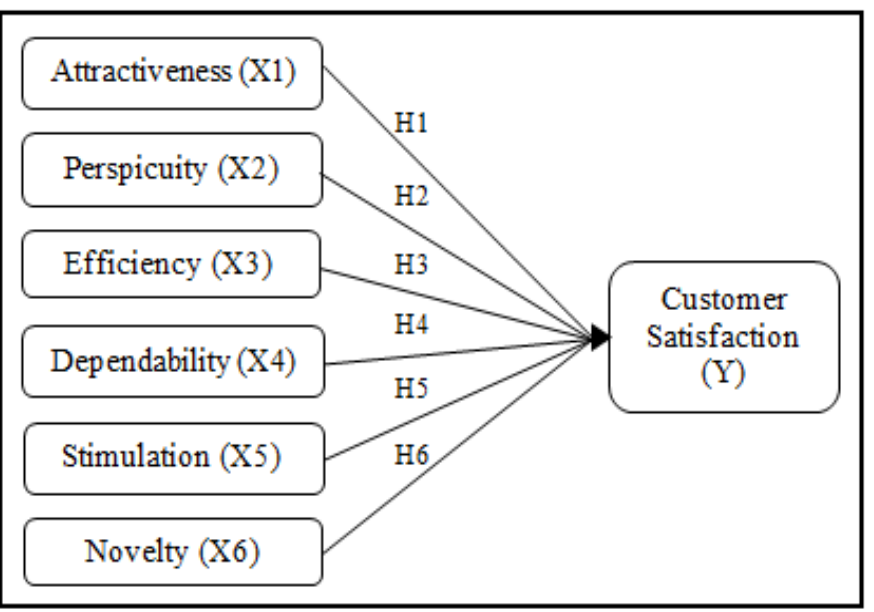

Source: (Rezaldy \& Telkom, 2019)

Fig 1:- framework

H1: Attractiveness has a significant effect on customer satisfaction on Netflix application users.

$\mathrm{H} 2$ : Perspicuity has a significant effect on customer satisfaction on Netflix application users.

H3: Efficiency has a significant effect on customer satisfaction on Netflix users.

H4: Dependability has a significant effect on customer satisfaction, partially on Netflix application users.

H5: Stimulation has a significant effect on customer satisfaction on Netflix users.

H6: Novelty has a significant effect on customer satisfaction on Netflix users.

\section{RESEARCH METHODOLOGY}

\section{A. Population and Sample}

The population in this study is Netflix online streaming users. The sampling technique used in this study is convenience sampling. Samples taken in this study were 150 respondents.

Collecting data in this study sourced from primary data is data created by researchers to solve research problems. Primary data were obtained directly from respondents. Primary data obtained from the object of research through direct and indirect observation, as well as filling out the questionnaire using Google forms provided to respondents Netflix users.

\section{B. Analysis Techniques}

The analytical method used in this study uses SEM (Structural Equation Model). This research uses the SEM method because it can display the observed concepts and can explain the overall model. Using SEM requires computer software (computer software) in this study will use Amos version 2.6. SEM has two parts. The structural model (Structural Model) and SEM model testing can be divided into two main parts, namely, measurement model and structural model.

\section{Object of Research}

Netflix is a digital streaming service provider founded by Reed Hastings and software executive Marc Randolph in 1997. Initially, Netflix provided DVD rental and sales services through the netflix.com website. In 1999, Netflix began providing unlimited DVD rental services with a monthly subscription system at a low price. In a year, Netflix introduced a personalized movie recommendation service system. This system uses the value given by each Netflix member to predict DVD movie choices, which is similar to the current rating.

In 2007, Netflix began to introduce streaming services. This service allows its customers to be able to watch live TV shows and movies on their personal computers. Until 2010, several electronics companies were partnered with Netflix to become partners. The electronics companies include Xbox 360, Blu-ray players, TV decoders, PS3, TV companies, Apple devices, and many others. It makes Netflix customers have many streaming media choices that make it easy for them to enjoy Netflix services.

In 2011, Netflix was launched outside the United States, starting in the Latin American and Caribbean regions. Access to Netflix's streaming service was extended to European countries two years later. In 2012, Netflix won its first Primetime Emmy Engineering Award. A year later, Netflix launched the original program, which is a program that is produced by Netflix. Many of his original shows won several TV awards and prestigious films, from the Emmy Primetime to the Oscar awards (https://media.netflix.com/en/about-netflix, n.d.) 
In January 2016, Netflix Co-founder and CEO Reed Hastings announced the expansion of the Netflix streaming service to reach 130 countries, including Indonesia. Reed Hastings announced this when he was on the stage of the 2016 Consumer Electronics Show (CES) in Las Vegas, United State (BAGUS PRASETIYO, 2016).

Netflix takes a winding road in Indonesia. The challenge faced by Netflix at the time was that access blocked by Telkom Group, the largest internet service provider in Indonesia. It has caused many people in Indonesia who have difficulty accessing Netflix services (ATMOKO, 2020).

On July 7, 2020, Telkom Group officially unblocked it after Netflix obeyed the Self Regulatory Code for Video Subscription on Demand Industry in ASEAN regulations. It is a rule not to display prohibited content in the form of content that violates copyright, contains child pornography, terrorism, and violates Intellectual Property Rights (IPR) as well as discrediting certain groups of people. (Jannah, 2020)

\section{DISCUSSION}

\section{A. Test Validity and Reliability}

Construct validity refers to the extent to which a collection of measured variables represents the theoretical latent construct those variables are designed to live.

Psychometric measurement theory means measurement models should be specified as congeneric. Standardized loading estimates should be 0.5 or higher, and ideally, 0.7 or higher, to point convergent validity. AVE should be 0.5 or greater, to suggest adequate convergent validity. AVE estimates for two factors also should be greater, than the square of the correlation between the two factors to supply evidence of discriminant validity. Construct reliability should be 0.7 or higher to point adequate convergence or internal consistency (Hair et al., 2018).

Reliability refers to a measure of the degree to which the indicators of a latent construct are internally consistent with each other. The indicators of highly reliable constructs are highly interrelated, indicating that they all seem to measure the same thing. Individual item reliability can be computed as 1.0 minus the measurement error variance. Note that high reliability is necessary, but not sufficient, condition for validity.

Validity and Reliability Testing Table

\begin{tabular}{|c|c|c|c|c|c|c|}
\hline Latent Variable & Indicator & Loading Factor & Conclusion & $A V E>0,5$ & $\mathrm{CR}>0,7$ & Conclusion \\
\hline \multirow{6}{*}{$\begin{array}{l}\text { Attractiveness } \\
\text { (X1) }\end{array}$} & X1 --> X1.1 & 0,804 & Valid & \multirow{6}{*}{0,546} & \multirow{6}{*}{0,878} & \multirow{6}{*}{ Reliable } \\
\hline & X1 --> X1.2 & 0,778 & Valid & & & \\
\hline & X1 --> X1.3 & 0,722 & Valid & & & \\
\hline & X1 --> X1.4 & 0,640 & Valid & & & \\
\hline & X1 --> X1.5 & 0,736 & Valid & & & \\
\hline & X1 --> X1.6 & 0,744 & Valid & & & \\
\hline \multirow{4}{*}{ Perspicuity (X2) } & X2 --> X2.1 & 0,734 & Valid & \multirow{4}{*}{0,623} & \multirow{4}{*}{0,868} & \multirow{4}{*}{ Reliable } \\
\hline & X2 --> X2.2 & 0,783 & Valid & & & \\
\hline & X2 --> X2.3 & 0,812 & Valid & & & \\
\hline & X2 --> X2.4 & 0,824 & Valid & & & \\
\hline \multirow{4}{*}{$\begin{array}{l}\text { Efficiency } \\
\text { (X3) }\end{array}$} & X3 --> X3.1 & 0,792 & Valid & \multirow{4}{*}{0,616} & \multirow{4}{*}{0,865} & \multirow{4}{*}{ Reliable } \\
\hline & X3 --> X3.2 & 0,788 & Valid & & & \\
\hline & X3 --> X3.3 & 0,795 & Valid & & & \\
\hline & X3 --> X3.4 & 0,765 & Valid & & & \\
\hline \multirow{4}{*}{$\begin{array}{l}\text { Dependibility } \\
\text { (X4) }\end{array}$} & X4 --> X4.1 & 0,791 & Valid & \multirow{4}{*}{0,611} & \multirow{4}{*}{0,862} & \multirow{4}{*}{ Reliable } \\
\hline & X4 --> X4.2 & 0,767 & Valid & & & \\
\hline & X4 --> X4.3 & 0,817 & Valid & & & \\
\hline & X4 --> X4.4 & 0,749 & Valid & & & \\
\hline \multirow{4}{*}{$\begin{array}{l}\text { Stimulation } \\
\text { (X5) }\end{array}$} & X5 --> X5.1 & 0,778 & Valid & \multirow{4}{*}{0,647} & \multirow{4}{*}{0,879} & \multirow{4}{*}{ Reliable } \\
\hline & X5 --> X5.2 & 0,733 & Valid & & & \\
\hline & X5 --> X5.3 & 0,817 & Valid & & & \\
\hline & X5 --> X5.4 & 0,882 & Valid & & & \\
\hline \multirow{3}{*}{$\begin{array}{l}\text { Novelty } \\
\text { (X6) }\end{array}$} & X6 --> X6.1 & 0,760 & Valid & \multirow{3}{*}{0,593} & \multirow{3}{*}{0,853} & \multirow{3}{*}{ Reliable } \\
\hline & X6 --> X6.2 & 0,758 & Valid & & & \\
\hline & X6 --> X6.3 & 0,781 & Valid & & & \\
\hline
\end{tabular}


ISSN No:-2456-2165

\begin{tabular}{|c|c|c|c|c|c|c|}
\hline & X6 --> X6.4 & 0,780 & Valid & & & \\
\hline \multirow{4}{*}{$\begin{array}{l}\text { Customer } \\
\text { Satisfaction } \\
\text { (Y) }\end{array}$} & Y --> Y.1 & 0,857 & Valid & \multirow{4}{*}{0,670} & \multirow{4}{*}{0,890} & \multirow{4}{*}{ Reliable } \\
\hline & Y --> Y.2 & 0,771 & Valid & & & \\
\hline & Y --> Y.3 & 0,797 & Valid & & & \\
\hline & Y --> Y.4 & 0,846 & Valid & & & \\
\hline
\end{tabular}

Table 1

Source: SEM Amos 2.6 Application

\section{B. The goodness of Fit Measurement}

Goodness-of-fit (GOF) is a measure that indicating how well a specified model structure reproduces the covariance matrix among the indicator variables, alternatively, the accuracy of a proposed theory(Hair et al., 2018).

SEM includes a measurement model that specifies the theoretical correspondence rules between measured and latent variables (constructs). The measurement model enables the computation of a proxy measure of the construct to represent any single independent or dependent construct with multiple items. By testing the fit of the theoretical measurement model against reality, one can assess the degree of measurement error present.

The model during this study was declared fit supported the GOF table obtained from the SEM Amos 26 Application.

\section{Goodness Of Fit (GOF) Measurement Table}

\begin{tabular}{|c|c|c|c|}
\hline GOF & Match Level & $\begin{array}{c}\text { The } \\
\text { calculation } \\
\text { results }\end{array}$ & Explanation \\
\hline CMIN/DF & $\begin{array}{c}\text { CMIN/df } \leq 5.00 \\
\text { (good fit) }\end{array}$ & 3,473 & Good fit \\
\hline RMSEA & $\begin{array}{c}\text { RMSEA } \leq 0.08 \\
\text { (good fit) } 0.08 \leq \\
\text { RMSEA } \leq 0.10 \\
\text { (marginal fit) } \\
\text { RMSEA } \geq 0.10 \\
\text { (poor fit) }\end{array}$ & 0,129 & Poor Fit \\
\hline CFI & $\begin{array}{c}\text { CFI } \geq 0.90 \text { (good } \\
\text { fit) } \\
0.80 \leq \text { CFI } \leq \\
0.90 \text { (marginal } \\
\text { fit) } \\
\text { CFI } \leq 0.80 \text { (poor } \\
\text { fit) }\end{array}$ & & \\
\hline
\end{tabular}

Table 2

Source: SEM Amos 2.6 Application

\section{Hypothesis Testing in Structural Model (Structural} Model Fit)

A structural theory is a conceptual representation of the structural relationships among constructs. The structural model component represents the proposed theory with a set of structural equations specifying what things are related or not related to each other(Hair et al., 2018).
Analysis of the overall model will determine the level of significance by looking at the value of $\mathrm{p}$. The estimated parameter values show results that are by the hypothesis and the level of significance $p<0.05$ then the hypothesis proposed means supported data or in other words accepted, however, if the estimated value of the parameter shows the results do not match the hypothesis and the significance level $\mathrm{p}>0.05$ then the hypothesis proposed means unsupported data or rejected. The results of testing the hypothesis in the overall model can be seen in the table below(Hair et al., 2018).

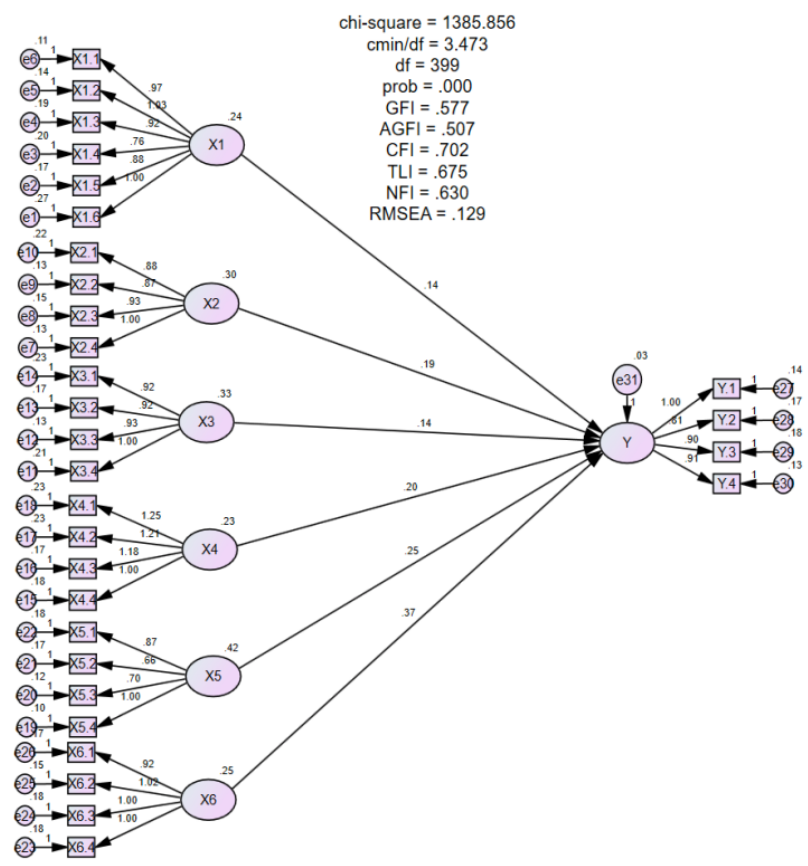

Source: SEM Amos 2.6 Application

Fig 2:- Structural Equation Model Diagram

Hypothesis Testing Table

\begin{tabular}{|c|c|c|c|c|}
\hline Hypothesis & Path & Estimate & P & Conclusion \\
\hline 1 & X1 $\rightarrow$ Y & 0,141 & 0,011 & Accepted \\
\hline 2 & X2 $\rightarrow$ Y & 0,187 & $* * *$ & Accepted \\
\hline 3 & X3 $\rightarrow$ Y & 0,144 & 0,003 & Accepted \\
\hline 4 & X4 $\rightarrow$ Y & 0,204 & $* * *$ & Accepted \\
\hline 5 & X5 $\rightarrow$ Y & 0,255 & $* * *$ & Accepted \\
\hline 6 & X6 $\rightarrow$ Y & 0,373 & $* * *$ & Accepted \\
\hline \multicolumn{5}{|c|}{ Table 3 }
\end{tabular}

Source: SEM Amos 2.6 Application 
All of the existing hypotheses, from $\mathrm{H} 1$ to $\mathrm{H} 6$ all can be accepted because the value of $p<0.05$ which shows all the hypotheses are supported by the research that all Independent variables strongly support the Dependent variable.

\section{CONCLUSIONS AND SUGGESTION}

\section{A. Conclusion}

$>$ Based on this research, there are many findings that almost all respondents of this study are very enthusiastic about the Netflix online streaming media user experience. Netflix users are almost dominated by Millennials.

$>$ In this study also, all indicators of the variable are interrelated between one variable with other variables.

$>$ This study also shows that all hypothesis testing can be accepted in this study.

$>$ In this research, most users are very satisfied with what Netflix provides in the experience of enjoying online streaming shows through Netflix.

\section{B. Suggestion}

\section{$>$ For Netflix}

Suggestions from researchers, hoping that airing on Netflix in addition to entertaining but also provide more education through each content of the film or series that aired and provide restrictions for violent scenes and those related to other vulgar scenes.

\section{For Further Researchers}

It is expected to broaden the reach of respondents and add several research variables such as Culture or Parental Guide (specifically for families with children under 18 years). Hopefully, it can be a reference for further research.

\section{REFERENCES}

[1]. Aryani, D., \& Rosinta, F. (2010). Pengaruh kualitas layanan terhadap kepuasan pelanggan dalam membentuk loyalitas pelanggan. Jurnal Ilmu Administrasi Dan Organisasi, 17(2), 114-126.

[2]. ATMOKO, B. D. (2020). Jalan Berliku Netflix di Indonesia. Gizmologi.Id. https://gizmologi.id/news/jalan-berliku-netflix-diindonesia/

[3]. BAGUS PRASETIYO. (2016). Layanan Streaming Film Netflix Masuk Indonesia. Tempo.Co. https://tekno.tempo.co/read/733881/layananstreaming-film-netflix-masukindonesia/full\&view $=$ ok

[4]. Hair, J. ., Black, W. C., Babin, B. J., \& Anderson, R. E. (2018). Multivaiate Data Analysis. Cenagage.

[5]. https://media.netflix.com/en/about-netflix. (n.d.). Netflix Media Centre.

[6]. Jannah, S. M. (2020). Telkom Grup Resmi Buka Blokir Netflix. Tirto.Id.
[7]. Kharis, Santosa, P. I., \& Winarno, W. W. (2019). Evaluasi User Experience pada Sistem Informasi Pasar Kerja Menggunakan User Experience Questionnare ( UEQ ). The 10th National Conference on Information Technology and Electrical Engineering, 24-25. http://citee.ft.ugm.ac.id/home.php?main=M2Z4Vw\%3 $\mathrm{D} \% 3 \mathrm{D}=\&$ part=REQ\%3D=

[8]. Kusuma, W. A., Noviasari, V., \& Marthasari, G. I. (2016). Analisis Usability dalam User Experience pada Sistem KRS Online UMM menggunakan USE Questionnaire. Jurnal Nasional Teknik Elektro Dan Teknologi Informasi (JNTETI), 5(4), 294-301. https://doi.org/10.22146/jnteti.v5i4.277

[9]. Mardalena Hutabarat. (2014). PENGARUH USER EXPERIENCE TERHADAP KEPUASAN PENGGUNA JEJARING SOSIAL PATH DI KOTA BANDUNG PADA TAHUN 2014. European Journal of Endocrinology, 171(6), 727-735.

[10]. Muhammad, F., Nugroho, R. A., \& Turianto N, D. (2016). Analisis User Experience Untuk Tingkat Keterpilihan Smartphone Android. Kumpulan Jurnal Ilmu Komputer, 04(01), 82-91.

[11]. Panjaitan, J. E., \& Yuliati, A. L. (2016). Pengaruh Kualitas Pelayanan Terhadap Kepuasan Pelanggan Pada JNE Cabang Bandung [The Influence of Service Quality on Customer Satisfaction at JNE Branch in Bandung]. DeReMa (Development Research of Management): Jurnal Manajemen, 11(2), 265. https://doi.org/10.19166/derema.v11i2.197

[12]. Raharjo, S., \& Japarianto, E. (2017). Pengaruh User Experience terhadap Behavior Intention to Use Digital Music Streaming Services dengan Attitude Toward Behavior sebagai Media Intervening. Jurnal Manajemen Pemasaran, 5(1), 1-11.

[13]. Rezaldy, I., \& Telkom, U. (2019). Pengaruh User Experience Terhadap Customer Satisfaction Pada Pengguna Aplikasi Iflix Effect of User Experience on Customer Satisfaction in Iflix. 6(1), 491-496.

[14]. Schrepp, M., Hinderks, A., \& Thomaschewski, J. (2017). Construction of a Benchmark for the User Experience Questionnaire (UEQ). International Journal of Interactive Multimedia and Artificial Intelligence, $4(4), \quad 40$. https://doi.org/10.9781/ijimai.2017.445

[15]. Setyo Riyanto. (2018). Pengambilan Keputusan Strategis (Mahpudi (ed.); 1st Editio). Paramedia Komunikatama. 